\author{
국균종의 임상적 고찰 \\ 순천향대학교 의과대학 내과학교실, 건양대학교 의과대학 내과학교실* \\ 김기업, 길효욱, 이석호, 김도진, 나문준*, 어수택, 김용훈, 박춘식 \\ $=$ Abstract $=$

\section{Clinical Characteristics of Aspergilloma} \\ Ki Up Kim, M.D., Hyo Wook Gil, M.D., Suk Ho Leө, M.D., \\ Do Jin Kim, M.D., Moon Jun Na, M.D.*, Soo-taek Uh, M.D., \\ Yong Hoon Kim, M.D., Choon Sik Park, M.D. \\ Department of Internal Medicine, Soonchunhyang University Haspital, Seoul, \\ Kunyang University*, Daejeon, Korea
}

Background : Pulmonary aspergilloma is relatively common in korea. It arises from the colonization and proliferation of Aspergillus in preexisting lung parenchymal cavities, in particular tuberculosis. The most common symptom in this disorder is hemoptysis, which may or may not be massive and life threatening. A routine chest radiography and computed tomography (CT) are the most important diagnostic procedures. A surgical resection of the aspergilloma has recently been recommended, because of the relatively low incidence of pastoperative complications than in the past. A more concentrated sample of patients with aspergilloma, who either underwent a thoracotomy or tested positive for aspergillus antibodies, were reviewed.

Method : The medical records of twenty-two patients with aspergilloma, who had a proven thoracotomy (9 cases), or who tested positive for the diagnostic procedure and/or aspergillus antibodies ( 13 cases) from January 1995 to December 2000, were reviewed retrospectively.

Results : The most common underlying lung disease was a current or old healed tuberculosis, and 3 patients had cultures of mycobacterium other than tuberculosis (MOTT). The mean time until the aspergilloma was detected 5.91 years in the healed tuberculosis cases. The others cases involved a lung abscess, bronchiectasis and

이 연구는 2001년 결핵 및 호흠기 하회에 발표된 내용입.

Address for correspondence :

Soo-taek Uh, M.D.

Department of Internal Medicine, Soonchunhyang University Hospital

\#657, Hannam-dong, Y ongsan-ku, Seoul, 140-743, Korea

Phone : 02-709-9195 Fax : 02-709-9554 E-mail : uhs@ hosp.sch.ac.kr 
without lung disease. The extrapulmonary disease was alcoholism and diabetes. Hemoptysis was most common in 72.7\%. A computed tomography (CT) is useful for diagnosis. The right upper lobe, especially the posterior segment, is the most common location. Bronchial artery embolization is ineffective for a long term follow-up. A lobectomy is most common in a thoracotomy, and intra-operative and post-operative complications are rare. During follow-up, the mortality rate, not from the aspergilloma but from respiratory failure, was $13.6 \%$.

Conclusion : Aspergilloma is a common cavitary lung disease, It mainly arises from tuberculosis, either current or healed, but extra-pulmonary disease including alcoholism or diabetes are other possible risk factors. Their most common problem in aspergilloma is hemoptysis. Surgery has a low risk of post-operative complications and is recommended in relatively preserved lung function or healthy patients. Medical maneuvers including embolization, and the local insertion of certain materials needs to be studied more closely. (Tuberculosis and Respiratory Diseases 2002, $52: 46-53$ )

Key words : Aspergilloma, Tuberculosis, Thoracotomy

\section{서 론}

폐 국규종(pulmonary aspergilloma)은 마성적인 진균감염 (saprophytic infection)으로서 방사선학적 으로는 air-crescent를 특징으로 하는 질환이다. 객 혈이 주요 증상이고, 주된 선행질환으로 폐결핵이 알 려져 있다. 국균(Aspergillus)으로 인한 페 질환 중 에서는 국균종이 비교적 흔히 볼 수 있는 절환이며 국 내에서는 강 등이 국균종의 임상양상에 대한 보고가 있다'. 대부분의 국균종은 증상이 없는 경우가 많아 정기 검사에서 우연히 발견되는 경우가 많다고 알려져 있다. Aspergillus species 포자가 호흡기계에 침범 하여 결핵성 공동이나 수술후의 폐장에 침범하여 균종 (mycetoma)을 형성하고 "fungus ball" 을 형성하다 고 알려져 있다. 전헝적인 국균종의 방사선학적 모양 은 공동개 고형 및 원형의 종괴가 공동의 벼과 분리되 어 존재한다. 혈청학적 검사가 진단에 도움이 되지만 확진할 수 있는 김사는 아니라고 알려져 있으나 외과 적 적출 후에는 항체의 감소 및 소멸을 확인할 수 있 달. 치료에서는 항진균재를 포함한 보존적 치료와 수 술이 있는데, 최근에는 환자의 전신상태가 양호한 경 우 수술이 선호되는 경향을 보인다45. 이에 저자들은 방사선 검사에서 국균종이 의심되는 환자 중 수술로서
확진이 되거나 기관지경을 퉁한 진균 배양 및 경피적 침생검으로 진균이 확진된 환자 또는 국균항체 양성으 로 파정되 홪자의 임상 양상에 대하여 알아보고자 하 였다.

\section{대상 및 방법}

1995년 1월부터 2000년 12월까지 문진과 진찰소견, 일반 혈액검사, 단순 훙부 방사선 검사(chest PA) 와 전산화단층촬영 (computed tomography: CT) 및 고해상도 전산화단층촬영 (high resolution computed tomography : HRCT)에서 국균종 이외의 세균감 염을 배제할 수 있는 경우만을 선택하였다. 국균종이 의심되는 58 례 중 수술을 하여 확진된 경우 9 례, 국 균종 항체 양성 및 기관지 내시경 진균배양검사에서 국균을 보인 1 례, 경피적 침 생검으로 진균이 검출되 고 국균종에 대한 항체 양성을 보이는 3 례, 그리고 국 균항체 양싱을 보인 9 례를 대상으로 후향적 분석을 하였다.

\section{결 과}

환자는 남자 14 례, 여자 8 례 였으며, 평균나이는 50.3 
Table 1. Underlying lung characteristics in patients with aspergilloma

\begin{tabular}{lccc}
\hline \multicolumn{1}{c}{ Underlying Lung Disease } & Number & Classification & Number \\
\hline Tuberculosis & & Cured (MOTT*) & $11(2)$ \\
& 16 & Current (MOTT*) & $4(1)$ \\
Lung Abscess & 2 & MDR-TB $^{*}$ & 1 \\
Bronchiectasis & 1 & & \\
Emphysema & 1 & & \\
No Underlying Lung Disease & 2 & & \\
\hline
\end{tabular}

*MOTT : Mycobacterium other than tuberculosis

MDR-TB : multi-drug resistant tuberculosis

\pm 14.8 이었다. 기저질환으로는 항결핵제 투여 후 완 치 판정을 받은 후 발생한 11 례와 다제내성결핵 1 례, 국균종과 함께 결핵을 진단받은 현증 결핵 4 례를 포 함하여 폐결핵이 16 례 $(72.7 \%)$ 였으며, 이중 완치 판정을 받았으나 현재 견핵균 동정에서 비견핵항산균 (mycobacterium other than tuberculosis:MOTT) 이 베앙된 2 례와 현증 감엄에서 발건된 비결핵항산균 1 례가 있었다. 또한 5 례에서는 동반되는 기관지확장 증을 발건할 수 있었다. 4 명의 환사는 벙럭에서 2 회 의 항결핵제 투여를 받았으며, 다제내성결핵 환자는 세번째 항결핵제 치료 중이었다. 기타질환으로는 폐농 양 2 례 $(9.1 \%)$, 기관지확장증 1 례 $(4.5 \%)$, 폐기종 1 례 $(4.5 \%)$, 폐내 기저질환이 없는 경우 2 례 (9.1\%) 였다. 완치판정을 받은 결핵환자 11 례에서 첫 항결핵 졔 투여로 완치 판정을 받고 나서 국균종을 진단할 때 까지 기간은 $5.91 \pm 5.72$ 년이었다(Table 1). 호흡기 계이외의 질환으로 국균종의 발생에 영향을 줄 수 있 는 원인으로 빈번한 음주력을 보인 환자는 5계 (22.7 $\%)$ 였고 당뇨는 3 례 (13.6\%)였다.

내원시 환자기 호소하는 주소로는 객헐이 16 례 (72.7 $\%)$, 기침과 객담 2 례 $(9.1 \%)$, 우연히 발견된 2 례 $(9.1 \%)$, 전신쇄약감과 호흡곤란이 각 1 례 $(4.5 \%)$ 었 다. 임상증상으로는 기침, 객담, 그리고 호흡곤란이 동반된 7례 (31.8\%), 기침과 객담이 동반된 4 례 (18.2 $\%)$, 객담과 호홉곤란을 호소하는 경우가 각 1 례 (4.5 $\%$ ) 였다. 진찰소견은 병변부에서 호흡음에서 이상을

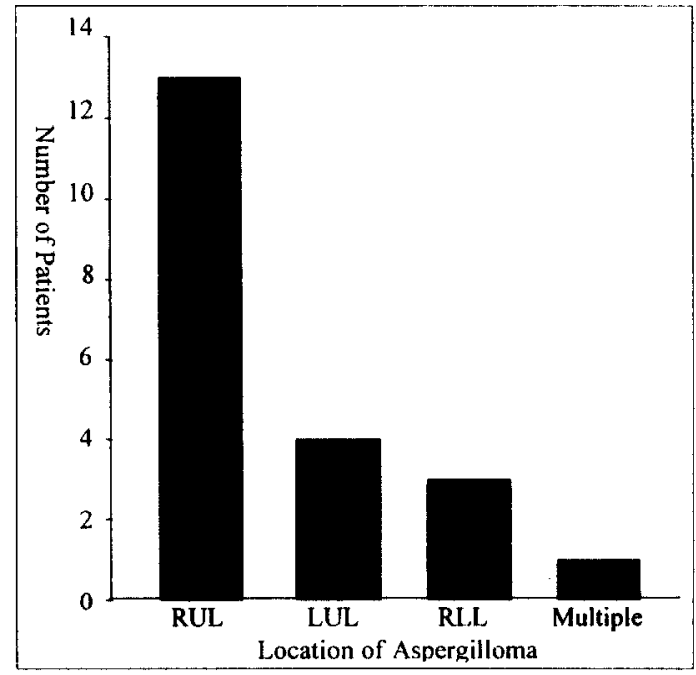

Fig. 1. Anatomical location of total patients with aspergilloma.

발견할 수 없는 14 례 $(63.6 \%)$ 와 기관지호흡음 3례 (13.6\%), 个포음 (crackles) 3례(13.6\%), 통음 (rhonchus) 2례 (9.1\%)였고, 중복되는 소견은 없었 다.

방사선 소견은 전산화단층촬영이 도움이 되었으며 fungal ball 11 례, air-meniscus sign 8례, 섬유화 및 낭포 1 례, 경화(consolidation)와 공동성 병변 (cavity) 각 1 례의 소견이었으며, 수술한 9 례는 fungal ball 6례와 air-meniscus sign을 보인 3례에서 시행되었다. 호발 부위는 우폐상엽 13 례, 좌폐상엽 4 
Table 2. Cause and method of operation in 9 cases of patients with aspergilloma

\begin{tabular}{lc}
\hline \multicolumn{1}{c}{ Cause of operation } & Number \\
\hline Massive hemoptysis & 5 \\
Recurrent hemoptysis & 2 \\
For preventive & 2 \\
\hline Method of operation & \\
\hline Lobectomy & 5 \\
Lobectomy and wedge resection & 2 \\
Bilobectomy & 1 \\
Wedge resection & 1 \\
\hline
\end{tabular}

례, 우폐하엽 3 례, 다발성 침범을 보이는 1 례 였다 (Fig. 1). 상업에서는 후분절이 8 예로 가장 많은 빈도 를 보였다.

진단은 홍부 방사선 및 컴퓨터 단충촬영에서 국균종 이 의심된 환자를 대상으로 9 례에서는 수술로 진단하 였고, 13 례의 국균종 항체 양성과 확진을 위하여 필 요한 경우에는 기관지내시경을 통한 배양검사를 1 례 에서, 3 례는 경피적침생검으로 하였다.

치료는 수술하지 않은 경우는 보존적 치료를 하였으 며 항진균제는 사용하지는 않았다. 기관지 동맥 색전 술은 4 례에서 시행하였으며 이는 수술한 2 례와 사망 한 2 례였다. 수술한 9 례의 환자에서 수술의 원인으로 는 빈번한 객혈 5 례, 대량객혈 2 계였으며 나머지 2 례는 예방적 수술이었다. 수술방법은 엽절제술 (lobectomy)이 5례로 가상 많았으며, 엽 및 왜기절제술 (wedge resection)이 2례, 두엽절제술(bilobectomy) 1례, 쐐기절제술 1 례였다(Table 2). 수술 및 수술의 경과 중 특기할 만한 합병증이나 사망은 없 었다.

국균종에 대한 항체 양성환자 13 명 중 추적검사는 평균 $33.6 \pm 20.6$ 개월이었고, 이 중 사망자는 3 명으 로 사인은 호홈부전 2 례와 홉인성 폐렴 1 례였다.

\section{고 찰}

사람에서의 국균감엄에 대한 첫 기술은 1856년
Virchow 에 의하여 처음 기술되었고 Hinson 등에 의 하여 알레르기성, 침윤성 그리고 국균종으로 분류되었 다 ${ }^{6}$. 국균종의 유병률은 정확하게 알려져 있지는 않 다․ 일부의 보고에 의하면 약 6000 명에 1 명, 또는 10,000 명에 1 명으로 보고된 바 있다8,9. 영국 결핵협 회는 결핵성 공동을 가지고 있는 환자의 $11 \%-17 \%$ - 가 방사선 소견에서 국균종을 보인다고 보고한 바 있 다 ${ }^{10}$. 국균종의 발생은 주로 누인에서 빈번하다고 알려 져 있으나 어느 연령에서도 보일 수 있다고 알려져 있 으며 소이에서도 발생한다고 알려져 있다" ${ }^{\prime \prime}$ 본 연구에 서는 연령별 분포가 다양하였는데 이는 기저질환 및 대상환자의 차이가 있었을 것으로 추정된다.

일반적으로 국균종은 Aspergillus fumigatus가 발견되지만, Aspergillus nigar, Aspergillus flavus, Aspergillus nidulans 및 다른 중류도 보고되었다'2. 본 연구에서는 국균종에 대한 구체적인 분류는 하지 못하였다.

병태생리는 기존의 공동성 병변에 국균의 집락과 증 식으로 발생한다고 추정되고 있으나 어떤 요인들이 작 용하는지에 대하여는 알려져 있지 않다. 결핵 ${ }^{10}$ 이 가 장 빈번한 기저질환으로 알려져 있으나 공동을 형성하 는 질환들인 유육종, 공동성 종양, 폐섬유중, 폐농양, 기관지 낭종, 석면증, 폐렴, 심장질환, 기관지학장증, 폐경색, 알레르기성 기관지 폐 국균증, 그리고 침윤성 국균증 등에서도 발생할 수 있다고 보고되었다. 본 연구에서도 결핵에 현재 이환되었거나 완치 판정을 받 은 환자에서 추로 발생하였으나, 결핵이외의 기관지 및 폐 실질의 병변에 의한 공동을 형성하는 질환들에 서 발생한다는 것을 확인할 수 있었다. 강 등'의 보고 에서도 기저질환의 원인별 분류는 본 연구와 비슷하였 으나 톡기 할 만한 사항으로는 현증 결핵과 동반되거 나, 비결핵항산균 환자에서도 국균종이 발견되었는데 이는 진단방법의 발전에 의한 것으로 추정되었다. 또 한 일부의 보고에서는 폐 이외의 질환으로 알콜에 의 한 간질환에서도 많은 빈도를 보인다는 보고가 있었으 며 ${ }^{3}$ 본 연구에서도 병력에서 빈번한 음주력이 있는 경우가 $22.7 \%$ 였으며, 당뇨 환자도 $13.6 \%$ 를 보여 전신상태가 질병의 발생에 엉향을 주는 것으로 확인되 
었다.

조식병리학적 소견은 진균성 공농내 송괴 (mycelic intracavitary mass)와 섬유소, 점액, 비정형 부스러 기(amorphous debris), 염증세포, 퇴화된 혈액 및 상피세포로 구성되어있다. 공동내 벽은 기관지 상피세 포(bronchial epithelium)로 구성되어 있거나 잘 발 달된 혈관과립조직(vascular granulation tissue)으 로 구성되어있다. 주변의 폐장은 다양한 정도의 폐렴 을 동반한다고 알려겨 있다?

국균종의 경과는 잘 알려져 있지는 않지만 죽은 진 균들이 분절(fragmentation) 되고 용해 (liquefaction)되어 객담으로 배출되기도 하며, 크기가 커지거 나 줄어들기노 하며 장기간 변화가 없는 경우도 있다 고 보고되었다 ${ }^{14.15}$. 스스로 소멸하는 경우도 7\%-10 $\%$ 보고되어 있고, 동반되는 세균감염이 공동의 용해 에 관여된다고 추정되고있다 ${ }^{10,16,17}$. 본 연구에서는 수 술적 방법이외의 자연소멸은 발견할 수 없었으며 추적 기간 동안 크기의 현저한 변화는 없었다.

가장 빈번한 합병증은 객혈로 알려져 있고, 그 발생 기전으로는 여러 가지 가설이 주장되어왔다. 첫 번째 로는 국균종이 공동의 벽과 마찰 및 기계적 운동으로 과밀된 혈관에 손상을 주면시 발생한다는 것이고 ${ }^{13}$, 둘 째로는 진균에서 생성된 녹소나 효소가 국소적 출혈을 유발할 수 있다는 것이며 ${ }^{18}$, 셋째로는 제 3 형 염증반응 에 의한 손상으로 공동벽의 변화가 오고 이로 인한 출 혈이 발생할 수 있는 것과 ${ }^{19}$, 넷째로 공동성 병변 이외 의 기관지염 (bronchitis) 과 기관염 (trachitis)이 동 반하여 발생할 수 있다고 하였다 ${ }^{20}$. 현재까지는 첫 번 째 가설이 신빙성이 높다고 알려져 있다.

임상양상은 주로는 증상이 없으며, 있는 경우는 아 주 다양하게 나타난다고 알려져 있다. 가장 흔한 증상 으로는 약 $74 \%$ 에서 객혈이 발생한다고 알려져 있으 며 ${ }^{7}$, 이는 국내에서 강 등의 보고 및 본 연구와 일치 하는 소견이다. 일반적으로는 객혈은 간헐적이고 소량 이라서 알려셔 있으며, 때때로 첫 객혈시 생명을 위협 할 정도의 대량 객혈이 발생한다고 알려져 있어 이는 수술이 최선이라는 주장의 근거가 되고있다. 그 외의
증상으로는 기침, 호흡곤란, 전신쇄약감, 체중감소 둥 이 있고 발열은 드물다고 알려져 있다. 진찰소견과 일 반적인 검사소견에서 특이한 것은 없으며 객담 진균배 양에서 빈번한 배양 검사 양성은 국균종의 약 $58 \%$ 에 서 보인다고 한다. 국균종에 의한 대량의 객혈은 드물 고 또한 세균감염 역시 드물다고 알려져 있다. 환자의 읶상경과나 예후는 환자의 동반되는 호흡기 질환 및 전신 상태에 의하며 국균종에 의한 사망은 드물다고 알려져 있다. 본 연구에서도 사망한 3 례에서 직접 사 인으로 국균종 보다는 다른 원인에 의한 것이어서 이 러한 주장을 뒷낟침 해주고 있다. 국균종 항원에 대한 침강 항체 (precipitating antibody)는 모두에서 발견 되어야 할 것으로 알려져 있으나 ${ }^{21}$, 소수에서 항원이 자극원이 될 수 없는 사진균 (nonviable fungal elements) ${ }^{20}$ 과 면역반응이 결여된 진균종 ${ }^{22}$ 에서는 예외 적으로 발생하지 않을 수 있다고 알려져 있으며 외과 적 절제술은 이러한 항체의 역가를 낮출 뿐 아니라 없 앨 수 있다고 알려져 있다 ${ }^{21,22}$

흥부 방사선에서는 둥근 고형의 종괴가 다양한 두께 를 가진 공동내 존재하고 공기에 의히여 분리되어 있 으며, 주로는 폐의 상부에 고립성으로 존재하지만 양 쪽이나 다발성으로도 날건할 추 있나. 또한 신균종이 벽과 떨어져 있는 경우에는 위치의 변화에 따른 변화 가 동반될 수 있다 ${ }^{23}$. 최근 연구에서는 전산화 단층촬 영이 진단에 유용하고 이는 진균종의 진단에 정확도를 증가시키는 것으로 알려져 있다24.

본 연구에서는 일반혈액검사 및 적혈구침강속도, 동 맥혈가스분석에서 이상이 있는지를 알아보았으나, 국 규종에 의한 차이를 발견할 수 없었다. 똔한 폐기능 검사가 예측치와 비교하였으나 차이를 발견할 수 없었 다.

진단은 흥부방사선에서 국균종에 특징적인 소견을 보이면 할 수 있지만, 헐청내 침강항체가 양성을 보이 면 정확도를 높일 수 있닥. 객담 배양에서 진균을 확 인하면 의심을 할 수 있으나 확진 할 수 있는 방법은 아니다.

치료는 주로 3 가지 관점이 있는데 이에 대한 논란 
이 많다. 치료에서 먼저 확인해야할 것으로는 환자상 태의 평가 및 질환에 대한 인식이 필요하다. 외과적 수술은 1948년에 Gerstl 등 ${ }^{25}$ 에 의하여 성공적인 수 술이 발표되었으며, 최근에는 폐기능이 수술적 치료에 장애가 되지 않는다면 주된 근치적 방법으로 대두되고 있다4,5.6. 수술의 이점은 증상의 조절과, 객혈을 에방 할 수 있으며 생명을 연장할 수 있다. 하지만 과거에 는 수술 후 발생하는 합병증으로 인한 사망률 또한 낮 지 않은 것으로 보고되고 있다 ${ }^{26}$. 최근의 보고에 의하 면 외과적 수술의 발전과 조기에 수술올 시행할 때 합 병증 발생이나 사망률이 현저한 감소를 보였다고 보고 되었다 ${ }^{4.5}$. 국내에서 강 둥'의 보고는 $3.9 \%$ 의 사망률 과 $7.9 \%$ 의 합병증을 보였으나 본 연구의 수술한 9 례 는 비교적 폐기능이나 전신상태가 양호한 환자들로서 사망 또는 기타의 합병중을 발견할 수 없었다. 이는 그간의 수술 방법 및 수술 후 합병증의 예방 방법의 발달과 수슬 환자의 전신상태에 의한 결과로 추ㅈㅓㅓㅇㄷㅚ 며, 이러한 결과가 국균종 환자에서 수술을 적극적으 로 권장할 수 있는 근거가 될 누 있을 것이다. 보존적 치료는 Amphotericin B를 이용한 치료가 주된 역할 을 하였으나 정맥주사 치료는 효과가 없는 것으로 판 정되었으며 ${ }^{27}$, 항진균제, sodium iodide 및 $5 \% \mathrm{dex}$ trose의 공동내 주입이 시도되었으나 효과에 대하여는 아직 논란의 여지가 많다. 또한 기관지동맥색전술에 대한 기대 역시 만족스럽지 못하다. 이는 공동으로 기 관지, 액와 및 쇄골하동맥에 의한 풍부한 헐류 공급과 출혈되는 혈관을 확인하는 것이 어렵고, 다량의 측부 순한(collateral circulation) 및 빈번한 신쳘간 생성 (neovascularization)에 의한다고 알려져 있다 ${ }^{28}$. 본 연구에서도 4 례에서 시행하였는네 걸과는 실망스러웠 다. 하지만 수술전 시행한 기관지동맥색전술이 수술 후의 합병증을 줄이는데 도움을 줄 수 있다고 최근에 보고가 되었다 ${ }^{29}$. 일부의 보고에 의하면 공동내 iodide 를 주입하여 줗은 효과를 보았다는 보고가 있으며 ${ }^{30}$ 비록 한 례 이지만 항진균제의 홉입으로 좋은 효과를 보고한 경우도 있었다 ${ }^{31}$.

결론적으로 국균종은 결핵 및 기타 공동을 형성하는
질환에서 호발하는 질환이며 다량의 객혈이나 빈번한 객혈이 문제가 될 수 있다. 전신상태가 양호한 환자에 서 수술이 추후에 발생하는 객혈을 비롯한 합병증 예 방에 최선의 치료이지만, 전신상태가 불량하고 폐기능 의 장애가 있는 환자에 대한 합병증 예방 및 근치적 치료에 여러 방법이 대두되는 비 좀더 적극적인 접근 이 요구된다 하겠다.

\section{요 야}

\section{연구배경 :}

폐 국균종은 우리나라에서 비교적 흔히 볼 수 있는 만 성적인 진균감염으로서 방사선학적으로는 air-crescent를 톡징으로 하는 질환이다. 객혈이 주요 증상이 고, 주된 선행질환으로 폐결핵이 알려져 있다. 진단은 방사선학적으로 공동내 고형 및 원형의 종괴가 공동의 벽괴 분리되어 존제히는 것이며 헐청학적 검시기 진단 에 도움이 된다. 치료에서는 항진균제를 포함한 보존 적 치료와 수술이 있는데, 최근에는 환자의 선신상태 가 양호한 경우 수술이 선호되는 경향을 보인다. 저자 들은 국균종이 의심되는 환자 중 수술로서 확진이 되 거나 국균항체 양성으로 판정된 환자의 임상 양상에 대하여 알아보고자 하였다.

\section{대상 및 방법 :}

1995년 1월부터 2000년 12월까지 문진과 진찰소견, 단순 향부 방사선 검사와 전산화단충활영에서 국균종 이 의심되는 58 례 중 수술올 하여 확진된 경우 9 례, 기관지 니시경 및 경피적 침 생검과 국균종에 대힌 항 체 양성을 보이는 13 례를 대상으로 후향적 분석을 하 였다.

결 과:

1) 기저질환으로는 폐결핵이 16례(72.7\%)였으며, 이중 현재 결핵균 동정에서 비결핵항산균이 3 례가 있 었다. 완치판정을 받은 결핵환자에서 국균종을 진단할 때까지 기간은 $5.91 \pm 5.72$ 년이었다. 기타로 폐농양 2 례 $(9.1 \%)$, 기관지확장증 1 례 $(4.5 \%)$, 폐기종 1 례 $(4.5 \%)$, 폐내 기저질환이 없는 경우 2 례 $(9.1 \%)$ 였 
다. 호흡기계이외의 질환으로는 빈번한 음주력 ( 22.7 $\%$ ) 과 당뇨 $(13.6 \%$ ) 였다. 2) 주소로는 객혈이 16 례 $(72.7 \%)$ 로 가장 많았으며, 진찰소견은 호흡음에서 이상을 발견할 수 없는 경우가 가장 많았다. 검사실 소견에서는 적혈구 침강속도의 증가 외에 특이사항을 발견할 수 없었다. 방사선 소견은 전산화단층촬영이 도움이 되었으며 주된 소견으로는 “fungal hall” 과 “air-meniscus sign”이었다. 호발부위는 폐 상엽, 특 히 후분절이 가장 많은 빈도를 보였다. 3) 기관지 동맥 색전술의 효과를 확인 할 수 없었으며, 수술방법 은 엽질제술(lobectomy)이 가장 많았고 수술 및 수 술의 경과 중 특기할 만한 합병중이나 사망은 없었다. 추적검사에서 사망률은 $13.6 \%$ 였으나 국균종에 의한 것은 아니었다.

\section{결 론 :}

국균종은 결핵 및 기타 공동을 형성하는 질환에서 호 발하는 질환이며 다량의 객혈이나 빈번한 객혈이 문제 가 될 수 있다. 전신상태가 양호한 환자에서 수술이 추후에 발생하는 객혈을 비롯한 합병증 예 방에 최선의 치료이지만, 전신상태가 불량하고 폐기능의 장애가 있 는 환자에 대한 합병증 예방 및 근치적 치료에 여러 낭법이 대두되는 바 좀더 적극적인 접근이 효구된나 하겠다.

\section{참 고 문 헌}

1. 강태경, 김창호, 박재용, 정태훈, 손정호, 이준호 등. 폐국균종의 임상적 고찰. 결핵 및 호흡기질환 1997;44:1308-17.

2. Kawamura S, Maesaki S, Tomono K, Tashiro T, Khono S. Clinical evaluation of 61 patients with Pulmonary Aspergilloma. Intern Med 2000;39: 209-212.

3. Maesaki S, Kawamura S, Hashiguchi K, et al. Evaluation of sandwich ELISA galactomannan test in samples of positive LA test and positive Aspergillus antibody. Intern Med 1999;38:948-
50.

4. Chen $\mathrm{J}-\mathrm{C}$, Chang $\mathrm{Y}-\mathrm{L}$, Luh S-P, Lee J-M, Lee Y -C. Surgical treatment for pulmonary aspergilloma : a 28 year experience. Thorax1997;52:810 $-3$.

5. El Oakley R, Petrou M, GoldstrawP. Indication and outcome of surgery for pulmonary aspergilloma. Thorax 1997;52:813-5.

6. Bavatasi G, Massetti M, Chapelier A, Fadel E, Macchiarini P, Khayat A, Dartevelle P. Surgical Treatment of Pulmonary Aspergilloma : Current Outcome. J Thorac Cardiovasc Surg 2000;119: 906-12.

7. Glimp RA, Bayer AS. Pulmonary A spergilloma: diagnostic and therapeutic consideration. Arch Intern Med 1983;143:303-8.

8. Varkey B, Rose HD. Pulmonary A spergilloma:A rational approach to treatment. Am J Med 1976; 61:626-31

9. McPherson P. Pulmonary Aspergillosis in A rgyll. Br J Dis Chest;1965:59:148-157.

10. British and Thoracic and Tuberculosis Association. Aspergilloma and residual tuberculosis cavities: The results of a resurvey. Tubercle 1970; 51227-45.

11. Evans EGV, Watson DA, Matthews NR. Pulmonary aspergillomata in a childhood treated with clotrimazole. Br Med J 1971;4:599-600.

12. McCarthy DS, Pepys J. Pulmonary Aspergilloma:Clinical Immunology. Clin Allergy 1973;3: 5770 .

13. Butz RO, Zvetina JR, Leininger BJ. Ten-Year Experience with Mycetomas in Patients with Pulmonary Tuberculosis. Chest 1985;87:356-8.

14. Pimentel JC. Pulmonary Calcification in the tumor like form of pulmonary aspergillosis : Pulmonary Aspergilloma. Am Rev Respir Dis 1966; 
94:208-216.

15. 1/2Villar TG, Pimentel JC, A vila R. Some aspects of pulmonary aspergilloma in Portugal. Dis Chest $1967 ; 51: 402-5$.

16. Hammermann KJ, Christianson CS, Huntington 1, et al. Spontaneous lysis of aspergillomata. Chest 1973;64:697-9.

17. Garvey J, Crastnopol P, Weisz D et al. The surgical treatment of pulmonary aspergillomas. $\mathrm{J}$ Thorac Cardiovas Surg 1977;74:542-7.

18. Campbell MJ, Clayton YM. Bronchopulmonary aspergillosis : A correlation of the clinical and laboratory findings in 272 patients investigation for bronchopulmonary aspergillosis. Am Rev Respir Dis 1964;89:186-96.

19. Hilvering C, Stevens EAM, Orie NGM. Fever in aspergillus mycetoma. Thurax 1970;25:19 24 .

20. Faulkner SL, Vernon R, Brown PP, et al. Hemoptysis and pulmonary aspergilloma:Operative versus nonoperative treatment. Ann Thorac Surg 1978:25:389-392.

21. Longbottom JL, Peppys J, Clive FT. Diagnostic precipitin test in Aspergillus pulmonary mycetoma. Lancet 1964;1:588-9.

22. A vila R. Immunological study of pulmonary aspergilloma. Thorax 1968;23:144-52.

23. Goldberg B. Radiological appearances in pulmonary aspergillosis. Clin Radiul 1962;13:106 14.

24. McGuinness G, Beacher JR, Harkin TJ, Garay
SM, Rom WN, Naidich DP. Hemoptysis :Prospective High Resolution CT/Bronchoscopic Correlation. Chest $1994 ; 105: 1155-62$.

25. Gerstl B, Weidman WH, Newmann AV. Pulmonary aspergillosis : Report of two cases. Ann Intern Med 1948;28:662-5.

26. Daly RC, Pairolero PC, Piehler JM, Trastek VF, Payne WS, Bernatz PE. Pulmonary aspergilloma. Ann Thorac Surg 1986;86:981-8.

27. Hammermann KJ, Sarosi GA, Tosh FE. A mphotericin $B$ in the treatment of saprophytic forms of pulmonary aspergillosis. Am Rev Respir Dis 1974;109:57-62.

28. Uflacker R, Kaemmerer A, Neves C, Picon CD. Management of massive hemoptysis by bronchial artery embolization. Radiology 1983;146:627-34.

29. Otani Y, Y oshida I, Ohki S, Kano M. Kawashima O, Suzuki M, et al. Arterial Embolization as Preoperative Treatment for Pulmonary Aspergillosis with Hemoptysis. Surg Today 1997;27 :812-5.

30. Rumbak M, Kohler G, Eastrige C, WeinerMuram H, Gavant M. Topical treatment of life threatening haemoptysis from aspergilloma. Thorax 1996;51:253-5.

31. Mikami M, Nakamura S, Kawakami M. Pulmonary Aspergilloma Successfully Treated with Long-Term Intermittant Inhalation Therapy with Miconazole. Intern Med 1993:32:247-250. 